\title{
Artificial Neural Networks and Response Surface Methodology Approach for Optimization of an Eco-Friendly and Detergent-Stable Lipase Production from Actinomadura Keratinilytica Strain Cpt29
}

\author{
Noura Semache, ${ }^{1}$ Fatiha Benamia, ${ }^{1, *}$ Bilal Kerouaz, ${ }^{2}$ Inès Belhaj, ${ }^{3}$ \\ Selma Bounour, ${ }^{1}$ Hafedh Belghith, ${ }^{3}$ Ali Gargouri, ${ }^{3}$ Ali Ladjama ${ }^{2}$ \\ and Zeineddine Djeghaba ${ }^{1}$ \\ ${ }^{1}$ Laboratory of Applied Organic Chemistry, Chemistry Department, Faculty of Sciences, Badji Mokhtar University, \\ P.O. Box 12, 23000 Annaba, Algeria \\ ${ }^{2}$ Laboratory of Applied Biochemistry and Microbiology, Biochemistry Department, Faculty of Sciences, \\ Badji Mokhtar University, P.O. Box 12, 23000, Annaba, Algeria \\ ${ }^{3}$ Laboratory of Molecular Biotechnology of Eukaryotes, Centre of Biotechnology of Sfax, University of Sfax, \\ Road of Sidi Mansour Km 6, P.O. Box 1177, Sfax 3018, Tunisia \\ *Corresponding author: E-mail: fatiha.benamia@univ-annaba.org
}

Received: 09-21-2020

\begin{abstract}
This work mainly focused on the production of an efficient, economical, and eco-friendly lipase (AKL29) from Actinomadura keratinilytica strain Cpt 29 isolated from poultry compost in north east of Algeria, for use in detergent industries. AKL29 shows a significant lipase activity $(45 \mathrm{U} / \mathrm{mL})$ towards hydrolyzed triacylglycerols, indicating that it is a true lipase. For maximum lipase production the modeling and optimization of potential culture parameters such as incubation temperature, cultivation time, and Tween $80(\mathrm{v} / \mathrm{v})$ were built using RSM and ANN approaches. The results show that both the two models provided good quality predictions, yet the ANN showed a clear superiority over RSM for both data fitting and estimation capabilities. A 4.1-fold increase in lipase production was recorded under the following optimal condition: incubation temperature $\left(37.9^{\circ} \mathrm{C}\right)$, cultivation time $(111 \mathrm{~h})$, and Tween $80(3.27 \%, \mathrm{v} / \mathrm{v})$. Furthermore, the partially purified lipase showed good stability, high compatibility, and significant wash performance with various commercial laundry detergents, making this novel lipase a promising potential candidate for detergent industries.
\end{abstract}

Keywords: Lipase; Actinomadura keratinilytica; Optimization; RSM; ANN; Detergent.

\section{Introduction}

Lipases are glycerol ester hydrolases that catalyzes the hydrolysis of triacylglycerols to release diacylglyceride, monoacylglycerol, long-chain fatty acids and glycerol at the interface of oil and water. ${ }^{1}$ It has been reported that the first lipases were obtained from Penicillium oxalicum and Aspergillus flavus. ${ }^{2}$ Since, the lipases were considered as a great biotechnological and industrial catalyst after carbohydrases and proteases. ${ }^{3}$ Lipases are prevalent in nature and are produced by plants, animals, and microorganisms including fungi, bacteria, and actinomycetes. ${ }^{4}$ Recently, it has been reported that several actinomycete isolates are able to hydrolyze fats and oils. ${ }^{5}$ Microbial lipases are mainly extracellular and their production is significantly influenced by the culture medium parameters. Generally, the major factor influencing the lipase activity was the carbon source. The production of these lipases is generally conducted in the presence of oil, triacylglycerols, fatty acids, esters, glycerol, or Tweens. ${ }^{6,7}$ Microbial lipases play a major role in various fields such as the synthesis of organic chemicals and industrial applications. Development of lipase-based technologies for the synthesis of novel compounds increased their use. ${ }^{8}$ The main commercial 
application for hydrolytic lipases is their use in laundry detergents. Detergent enzymes make up nearly $32 \%$ of the total lipase sales. ${ }^{7}$ Approximately, sixty percent of industrial enzymes are hydrolytic in nature and are used by the detergent, dairy and leather industries. ${ }^{9}$

The main objective of this work is the production of an efficient, natural, and economical lipase for use in industrial applications and in particular the laundry detergent industry. For this purpose a novel lipase (AKL29) from Actinomadura keratinilytica strain Cpt29 isolated from poultry compost in local farm north east of Algeria, was produced. To our knowledge, the lipase cultivation from this strain has never been described. This study mainly focuses on the optimization of the parameters of culture medium to increase the production of AKL29. For this purpose artificial neural networks (ANN) and response surface methodology (RSM) have been investigated to build a predicted effects model and optimization of culture parameters of lipase production.

The last decade has seen a multitude of data analysis tools based on biological phenomena develop into well-established modeling techniques, such as artificial intelligence and evolutionary computing. Artificial neural network (ANN) is now the most popular machine learning tool in biotechnology. ${ }^{10}$ On the other hand, the statistical optimization of processes has advantages compared to the classical one. ${ }^{11}$ Numerous researchers have reported the use of statistical methods for the production of lipases by microorganisms. ${ }^{12}$

The classical method of optimization involves varying one parameter at time and ignoring the combined interactions between experimental conditions of the process. In recent years, the artificial neural network (ANN) has been used as a highly powerful and flexible method in various processes. It is expected to reveal functions representing phenomena but it cannot clarify the interaction among variables and the significance of each variable. Response surface methodology (RSM) is an effective statistical technique for developing, improving, and optimizing complex process. ${ }^{11}$

For an exhaustive study on the improvement of lipase production from Actinomadura keratinilytica strain Cpt29, both ANN and RSM as statistical approaches have been performed in the present work. After finding the most influential factors (incubation temperature, cultivation time, and Tween $80, v / v)$, for composition of production medium among several parameters of culture medium screened in our previous study, the optimization of these three significant parameters for maximum lipase production was carried out using RSM and ANN. In this work, also a partial purification was investigated to improve the lipolytic activity efficiency of the produced lipase. Furthermore, the stability, compatibility, and wash performance of the partially purified AKL29 with various laundry detergents were carried out to evaluate its potential as bio-additive in various detergents formulations.

\section{Experimental}

\section{1. Materials}

Candida rugosa lipase (CRL, Type VII, $760 \mathrm{U} / \mathrm{mg}$ ), Bradfordreagent, bovineserumalbumin(99\%)werepurchased from Sigma-Aldrich Chemie GmbH (Munich, Germany). Benzamidine were from Fluka (Buchs, Switzerland); Gum Arabic was from Merck (D-6100 Darmstadt, Germany), $\mathrm{pH}$-stat was from Metrohm (Switzerland). Unless specified otherwise, all substrates, chemicals, and reagents were of the analytical grade or highest available purity purchased from Sigma Chemical Co. (St. Louis, MO, USA). Sephacryl S-75 was from Pharmacia (Pharmacia, Uppsala, Sweden).

\section{2. Microorganism Source}

The organism required for the lipase production is a thermophilic actinomycetes Actinomadura keratinilytica strain Cpt29 [GenBank accession no. KC447297]. The strain Cpt 29 was isolated from poultry compost collected from a local farm in north-east region of Annaba, Algeria as previously described elsewhere. ${ }^{13}$ Stock culture of Actinomadura keratinilytica strain Cpt29 [C.p.t: Compost poultry thermophilic] was maintained by periodic subculture and stored at $4{ }^{\circ} \mathrm{C}$.

\section{3. Lipase Production}

The lipase production from Actinomadura keratinilytica strain Cpt29 was carried out as follows. Firstly, the bacterial isolate strain Cpt29 was subjected to a qualitative screening for lipase activity, using agar plates containing a slightly modified basal medium $(\mathrm{g} / \mathrm{L}): \mathrm{K}_{2} \mathrm{HPO}_{4}, 0.8$; $\mathrm{KH}_{2} \mathrm{PO}_{4}, 6 ;\left(\mathrm{NH}_{4}\right)_{2} \mathrm{SO}_{4}, 1 ; \mathrm{MgSO}_{4} .7 \mathrm{H}_{2} \mathrm{O}, 0.2 ; \mathrm{CaCl}_{2}, 0.5$; $\mathrm{NaCl}, 3 ; \mathrm{FeSO}_{4}, 0.001$, supplemented with $3 \%(\mathrm{v} / \mathrm{v})$ Tween 80; and bacteriological agar, $20 .{ }^{14}$ The medium was adjusted to different $\mathrm{pH}(4-10)$ in order to set the optimum $\mathrm{pH}$ of the culture medium, and the plates were incubated at $35{ }^{\circ} \mathrm{C}$ for three days. Lipase producing strain Cpt29 was identified by monitoring clear zone formation around the bacterial colony. Halo zones seen were considered as positive for lipase production.

Lipase production was carried out using a method similar to that described in previous work. ${ }^{15} 10 \mathrm{~mL}$ of inoculums culture was added in $100 \mathrm{~mL}$ of culture medium in $500 \mathrm{~mL}$ Erlenmeyer flasks and incubated at $35^{\circ} \mathrm{C}$ on a rotary shaker at $150 \mathrm{rpm}$ for three days. The culture broths were centrifuged at $4830 \mathrm{xg}$ for $20 \mathrm{~min}$ to remove mycelia and medium debris, and the cell-free supernatant was used as a crude enzyme solution for determination of the lipolytic activity.

\section{4. Lipase Activity Assay}

Lipase activity was measured titrimetrically using olive oil hydrolysis. According to previous works ${ }^{15-17}$ the 
experiments were performed using olive oil emulsion obtained by mixing $5 \mathrm{~mL}$ of olive oil with $45 \mathrm{~mL}$ of $10 \%$ $(\mathrm{w} / \mathrm{v})$ of gum arabic (GA) in $30 \mathrm{~mL}$ of $25 \mathrm{mM}$ Tris- $\mathrm{HCl}$ buffer (pH 8) in the presence of $2 \mathrm{mM} \mathrm{CaCl}_{2}$, and $200 \mu \mathrm{l}$ of enzyme solution. The quantity of free fatty acids (FFAs) released was titrated adding $0.1 \mathrm{~N}$ sodium hydroxide to the reaction medium. Hydrolysis of olive oil emulsion was monitored by $\mathrm{pH}$-stat (718 Stat Titrino, Metrohm, Switzerland). One unit (1U) of lipase activity corresponds to $1 \mu \mathrm{mol}$ of fatty acid released per minute under the assay conditions used. All determinations were performed in triplicate.

\section{5. Estimation of Total Extracellular Protein}

The total extracellular protein content was measured by Bradford method using Coomassie blue assay procedure and bovine serum albumin (BSA) as standard. Samples were analyzed in spectrophotometer (Jenway $6405 \mathrm{UV} / \mathrm{Vis})$ at $595 \mathrm{~nm}$ and the protein concentration was determined using the calibration curve of BSA. ${ }^{18}$

\section{6. Partial Purification of AKL29}

The partial purification of lipase from the isolate strain Cpt29 was carried out by two steps including acetone precipitation strategy and gel filtration on Sephacryl S-75. The experiments were performed at $4{ }^{\circ} \mathrm{C}$ using a method similar to that described in previous work..$^{19}$

\section{6. 1. Acetone Precipitation}

After the incubation period, the culture of strain Cpt29 (200 mL) grown on Tween 80 under optimal cultivation conditions was centrifuged for $20 \mathrm{~min}$ at 4830 $\mathrm{xg}$ to remove the microbial cells. The crude enzyme solution $(188 \mathrm{U} / \mathrm{mL})$ was submitted to the partial purification using acetone precipitation as important step. Four volumes of ice-cold acetone $\left(-20^{\circ} \mathrm{C}\right)$ were added to one volume of cell-free culture supernatant to remove most of the other proteins. To minimize the impurities as much as possible, the experiment was repeated with gradual increments of $3 \%$ acetone saturation under a gentle stirring. The precipitate was then recovered by centrifugation at $12000 \mathrm{xg}$ for $25 \mathrm{~min}$, and then was suspended in a minimal volume of $20 \mathrm{mM}$ Tris- $\mathrm{HCl}$ buffer $(\mathrm{pH} 8)$ containing $1 \mathrm{mM}$ benzamidine, and the protein content was estimated.

\section{6. 2. Filtration on Sephacryl S-75}

After the acetone precipitation step, the obtained supernatant was applied onto a column $(3 \mathrm{~cm} \times 160 \mathrm{~cm})$ of gel filtration Sephacryl S-75 equilibrated with $20 \mathrm{mM}$ Tris- $\mathrm{HCl}$ buffer $(\mathrm{pH}$ 8) containing $1 \mathrm{mM}$ benzamidine. The elution of lipase was performed with the same buffer solu- tion at a rate of $45 \mathrm{~mL} / \mathrm{h}$. All the elute fractions ( $2 \mathrm{~mL}$ each) were collected, and then were checked for lipase activity by titrimetric method. The fractions containing the lipase activity were pooled and the protein content was measured spectrophotomerically at $280 \mathrm{~nm} .{ }^{15}$

\section{7. Optimization of Lipase Production}

The optimization of lipase production from strain Cpt29 was carried out using two steps including the choice of the best carbon source and the culture medium optimization for maximum lipase production. The optimization of culture medium was investigated using RSM and ANN methodologies.

\section{7. 1. Selection of Carbon Source}

To select the significant substrate for AKL29 production, a screening study was performed using four different sources of carbon (Tween 80, Tween 20, olive oil and wheat bran). Each substrate was added to the basal medium at various concentrations to evaluate its effect on the lipase production. Kinetics of the lipase production were monitored by inoculation of $10^{6}$ spores $/ \mathrm{mL}$ in basal medium followed by incubation at $35^{\circ} \mathrm{C}$, under shaking condition. Samples were taken aseptically every day and enzyme activity was measured using a $\mathrm{pH}$-stat.

\section{7. 2. Statistical Analysis}

In order to study the effects of culture conditions on the lipase production, two different statistical approaches were performed for the modeling and the optimization of the lipase activity which is the response $(\mathrm{Y})$ of the experimental design and function of independent variables in RSM and training of the artificial neuron in ANN.

For this purpose a Box-Behnken design was performed to evaluate the effects of culture conditions on the activity of the produced lipase $(\mathrm{U} / \mathrm{mL})$, which is the response $(\mathrm{Y})$ of experimental design. A total of fifteen runs with different combination of the significant experimental factors were performed (Table 1). The culture medium conditions are expressed by the following factors $(\mathrm{Xi})$ : incubation temperature $\mathrm{X}_{1}\left(20-50{ }^{\circ} \mathrm{C}\right)$, cultivation time $\mathrm{X}_{2}\left(2-5\right.$ days), and Tween $80(\mathrm{v} / \mathrm{v})$ as carbon source $\mathrm{X}_{3}$ (2-4\%). A quadratic polynomial regression model (Eq. 1) was assumed to predict the optimal response $(\mathrm{Y})$. The proposed model for response $(\mathrm{Y})$ was:

$$
Y=\beta_{0}+\sum_{\mathrm{i}=1}^{\mathrm{k}} \beta_{\mathrm{i}} \mathrm{X}_{\mathrm{i}}+\sum_{\mathrm{i}=1}^{\mathrm{k}} \beta_{i i} \mathrm{X}_{\mathrm{i}}^{2}+\sum_{\mathrm{j}=1}^{\mathrm{k}} \beta_{i j} \mathrm{X}_{\mathrm{i}} \mathrm{X}_{\mathrm{j}}
$$

Where $\beta_{0}, \beta_{\mathrm{i}}, \beta_{\mathrm{ii}}$, and $\beta_{\mathrm{ij}}$ are the regression coefficients ( $\beta_{0}$ is the intercept term, $\beta_{\mathrm{i}}$ is the linear effect term, $\beta_{\mathrm{ii}}$ is the quadratic effect term, $\beta_{\mathrm{ij}}$ is the interaction effect term, and $\mathrm{Y}$ is the predicted response value); $\mathrm{X}_{1}, \mathrm{X}_{2}, \ldots, \mathrm{X}_{\mathrm{k}}$ are the input variables that explain the response $\mathrm{Y}^{11}$ 


\section{8. Influence of Laundry Detergents on Partially Purified Lipase Activity}

In this work, the enzymatic performance of partially purified AKL29 towards laundry detergents was verified by studying the effect of various brand commercial detergents on the stability and compatibility of lipase using the commercial Candida rugosa lipase (CRL) for comparison. Furthermore, wash performance of the partially purified AKL29 as a green additive for detergent, was evaluated. Effect of laundry detergents on the lipase activity was carried out using a method similar to that described in previous work. ${ }^{20}$

\section{8. 1. Influence of Detergents on the Lipase Stability and Compatibility}

The enzyme compatibility and stability of the partially purified AKL29 with laundry detergents were assessed using a variety of commercial detergents including, ARIEL (Procter and Gamble, Switzerland), ISIS (Henkel, Algeria), OMO (Unilever, Algeria), LE CHAT (Henkel, Algeria),

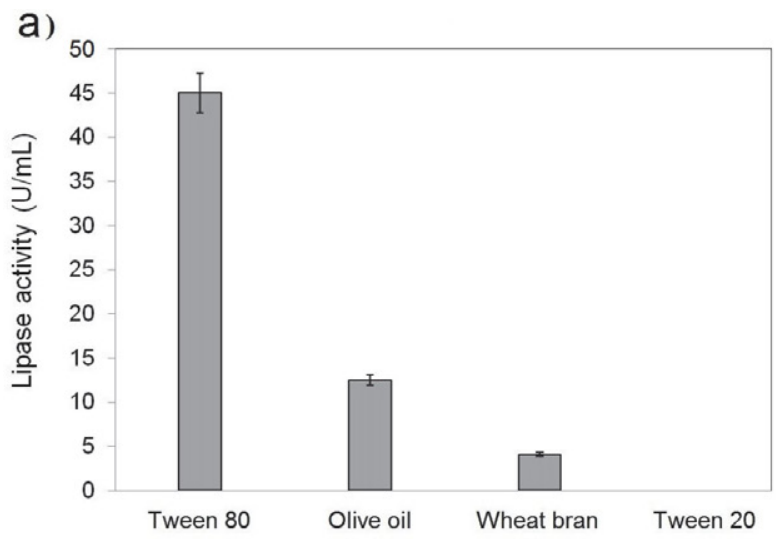

and NICE (Sarl Nice Plus, Algeria). All experiments were assessed using CRL as commercial lipase for comparative evaluation. In order to simulate the washing conditions, the selected commercial detergents were diluted in tap water to give a final concentration of $7 \mathrm{mg} / \mathrm{mL}$. All pre-existing endogenous lipases contained in these detergents were inactivated by heating the diluted detergents for $60 \mathrm{~min}$ at $70{ }^{\circ} \mathrm{C}$ before addition of the enzyme. The effect of lipase stability as well as its compatibility with commercial laundry detergents were studied by incubating each of the two lipases tested (AKL29 or CRL) with the various modified detergents at $40{ }^{\circ} \mathrm{C}$ for $60 \mathrm{~min}$. The residual activities were determined at $\mathrm{pH} 8$ and $45^{\circ} \mathrm{C}$ and the enzymatic activity in the absence of any detergent was taken as $100 \%$.

\section{8. 2. Wash Performance Analysis of Partially Purified Lipase}

The wash performance evaluation of partially purified AKL29 as eco-friendly additive in laundry detergent was investigated using small white cotton cloth pieces

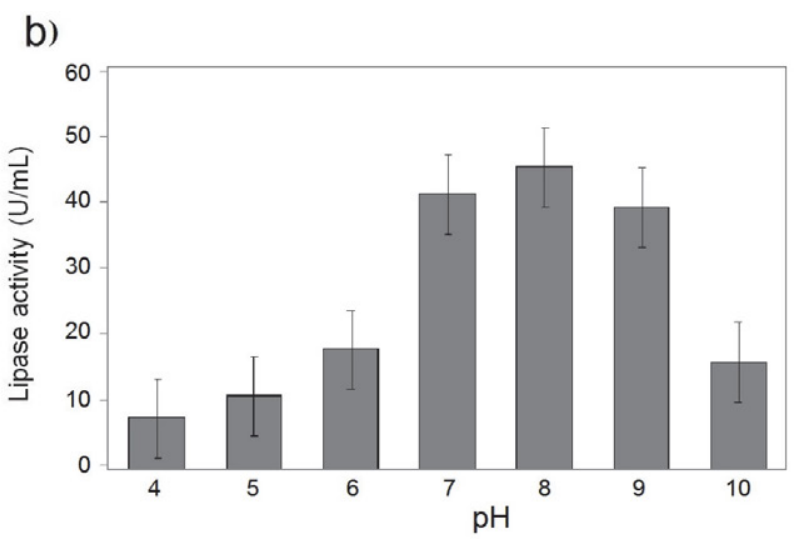

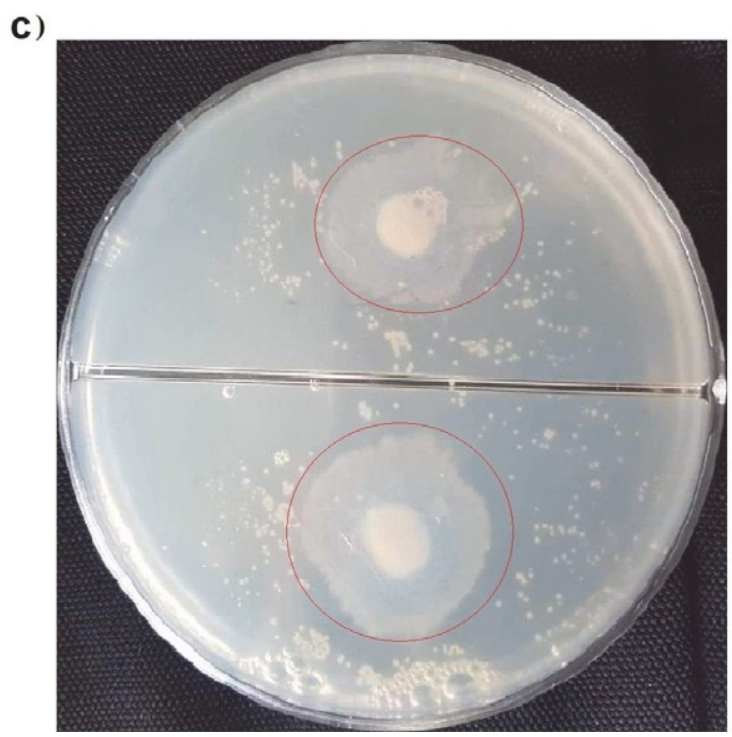

Figure 1. Influence of various carbon sources on the AKL29 activity (a). Effect of pH on the AKL29 activity (b). The lipase activities were measured at $35^{\circ} \mathrm{C}, \mathrm{pH} 8$, after three days using different carbon sources, and different $\mathrm{pH}$. The experiments were conducted three times and the error bars represent standard deviation. Hydrolysis zone formed by the lipolytic strain Cpt29 (c). 
stained with a mixture of sauce sample and fat/greasy material. The cloth pieces were then incubated in different wash treatments at $40{ }^{\circ} \mathrm{C}$ and stirred at $100 \mathrm{rpm}$ for $30 \mathrm{~min}$. Incubation process was carried out using $100 \mathrm{~mL}$ of modified detergent at final concentration of $7 \mathrm{mg} / \mathrm{mL}$ (heat inactivated). After incubation the modified detergent was added to the lipase solution $(50 \mathrm{U} / \mathrm{mL})$. After that, the cloth pieces were removed, rinsed with distilled water, dried and submitted to visual observation to examine the stain removal effects of the lipase. Olive oil was extracted with petroleum ether for $6 \mathrm{~h}$ using a Soxhlet extractor after complete evaporation of petroleum ether from the extract. The percentage of the removed olive oil was calculated by the following formula: ${ }^{20}$

$$
\operatorname{Removal}(\%)=\frac{W_{1}-W_{2}}{W_{2}} \times 100
$$

Where, $W_{1}$ and $W_{2}$ denoted the weights of total olive oil before and after washing $(\mathrm{mg})$, respectively.

\section{Results and Discussion}

\section{1. Selection of Carbon Sources}

To select the appropriate carbon source that maximizes the activity of lipase produced by strain Cpt29, various carbon sources such as Tween 80 , Tween 20, Olive oil, and Wheat bran were tested. The screened carbon sources were supplemented at $3 \%, \mathrm{v} / \mathrm{v}$ to the basal Mendel's medium. The effects of carbon sources on the lipase activity are illustrated by Figure 1a.

Figure 1a shows that the highest level of lipase activity $(45 \pm 2 \mathrm{U} / \mathrm{mL})$ was produced in presence of Tween 80 emulsion as substrate after three days of growth. The lower lipase activity of $4 \pm 1.5 \mathrm{U} / \mathrm{mL}$ was observed on media supplemented with oil olive as carbon source. Only Tween 20, present in the medium as carbon source, permits to decline significantly the lipase activity. Based on these results, Tween 80 was selected as the best carbon source for lipase production by isolate Cpt29. The produced lipase was assayed for its ability to hydrolyze Tween 80 as an exclusive carbon source, in agar plates incubated at $35{ }^{\circ} \mathrm{C}$ for three days. Lipase produced by strain Cpt29 was found more active over a range of $\mathrm{pH}$ from 7 to 9 , with an optimum at $\mathrm{pH} 8$ (Figure $1 \mathrm{~b}$ ). Colonies with a large clear zone formed by the hydrolysis of Tween 80 indicated the presence of lipolytic activity (Figure 1c).

\section{2. Optimization of AKL29 Activity}

Response surface methodology (RSM) using BoxBehnken design was applied to determine the optimal levels of the activity of lipase produced by strain Cpt 29 . RSM allows the analysis of the effects of significant culture parameters and also generates a mathematical model which makes it possible to predict the optimal response (Y). ${ }^{11}$ The evaluation of the resulting model (Table 2) was conducted by the statistical theory and analyzing data in Table 1 using Minitab 16 as statistical software.

The results of the analysis of variance (ANOVA, Table 2) show that the interaction terms are not significant $(P$-value $>0.05)$. So to improve data fit, these terms were excluded from this analysis. The final model is expressed in terms of linear terms $\left(\mathrm{X}_{\mathrm{i}}\right)$ and quadratic terms $\left(\mathrm{X}_{\mathrm{i}}^{2}\right)$ (Eq.3):

$$
\begin{aligned}
& Y=765+13.95 X_{1}+124.10 X_{2}+216.54 X_{3} \\
& -0.197 X_{1}^{2}-14.69 X_{2}^{2}-34.54 X_{3}^{2}
\end{aligned}
$$

Table 1. Experimental design used in RSM and ANN studies with the values of selected independent variables and the corresponding observed and predicted responses $(\mathrm{Y})$.

\begin{tabular}{lccccc}
\hline $\mathbf{X}_{\mathbf{1}}\left({ }^{\circ} \mathbf{C}\right)$ & $\mathbf{X}_{\mathbf{2}}$ (days) & $\mathbf{X}_{\mathbf{3}}(\mathbf{\%})$ & $\begin{array}{c}\text { Observed } \\
\text { values }\end{array}$ & $\begin{array}{c}\mathbf{Y}^{\mathbf{a}} \mathbf{( U / \mathbf { m L } )} \\
\mathbf{R S M} \text { predicted } \\
\text { values }\end{array}$ & $\begin{array}{c}\text { ANN predicted } \\
\text { values }\end{array}$ \\
\hline 50 & 5.0 & 3 & 147 & 142.63 & 146.71 \\
35 & 5.0 & 4 & 157 & 155.50 & 157.44 \\
20 & 3.5 & 2 & 51 & 49.88 & 51.25 \\
35 & 5.0 & 2 & 122 & 121.75 & 122.33 \\
35 & 2.0 & 4 & 57 & 61.75 & 57.13 \\
35 & 3.5 & 3 & 158 & 159.33 & 159.05 \\
50 & 3.5 & 2 & 73 & 77.38 & 73.44 \\
35 & 3.5 & 3 & 156 & 159.33 & 159.05 \\
35 & 2.0 & 2 & 31 & 28.00 & 30.74 \\
20 & 2.0 & 3 & 24 & 21.38 & 24.25 \\
50 & 2.0 & 3 & 48 & 48.88 & 48.05 \\
20 & 3.5 & 4 & 86 & 83.63 & 85.88 \\
35 & 3.5 & 3 & 164 & 159.33 & 159.05 \\
50 & 3.5 & 4 & 112 & 111.13 & 111.99 \\
20 & 5.0 & 3 & 109 & 115.13 & 108.60 \\
\hline
\end{tabular}

${ }^{\mathrm{a}}$ : values represent means of three replicates. Y: lipase activity $(\mathrm{U} / \mathrm{mL})$ 
Table 2. All estimated regression coefficients for response (Y).

\begin{tabular}{lcc}
\hline Term & Coefficient & $\boldsymbol{P}$-value \\
\hline $\mathrm{X}_{1}$ & 13.95 & 0.000 \\
$\mathrm{X}_{2}$ & 124.10 & 0.000 \\
$\mathrm{X}_{3}$ & 216.54 & 0.000 \\
$\mathrm{X}_{1}^{2}$ & -0.197 & 0.000 \\
$\mathrm{X}_{2}^{2}$ & -14.69 & 0.000 \\
$\mathrm{X}_{3}^{2}$ & -34.54 & 0.000 \\
$\mathrm{X}_{1} \mathrm{X}_{2}$ & 0.156 & 0.153 \\
$\mathrm{X}_{1} \mathrm{X}_{3}$ & 0.067 & 0.651 \\
$\mathrm{X}_{2} \mathrm{X}_{3}$ & 1.500 & 0.328 \\
\hline
\end{tabular}

The coefficient of determination $\left(\mathrm{R}^{2}\right)$ of the model adjusted to $99.21 \%$ tested the fit of the model and indicates the real relationship among the selected parameters. These values showed that the best model that fits our data is the quadratic one. The results (Table 2) show that the carbon source (Tween 80 ) and the culture time exhibite high influence on the production of lipase. This significance was evaluated by the high values of their effect compared to that of incubation temperature. Also the very meaningful Fisher's coefficient $\left(\mathrm{F}_{0.95}=3.58<<<292.42\right)$ with the high coefficient of determination $\left(\mathrm{R}^{2}=99.6 \%\right)$, and the study of the linear regression between the observed values of response $\left(\mathrm{Y}_{\mathrm{obs}}\right)$ and the predicted ones $\left(\mathrm{Y}_{\text {pred }}\right)$ confirm the validity of this model (Figure 2).

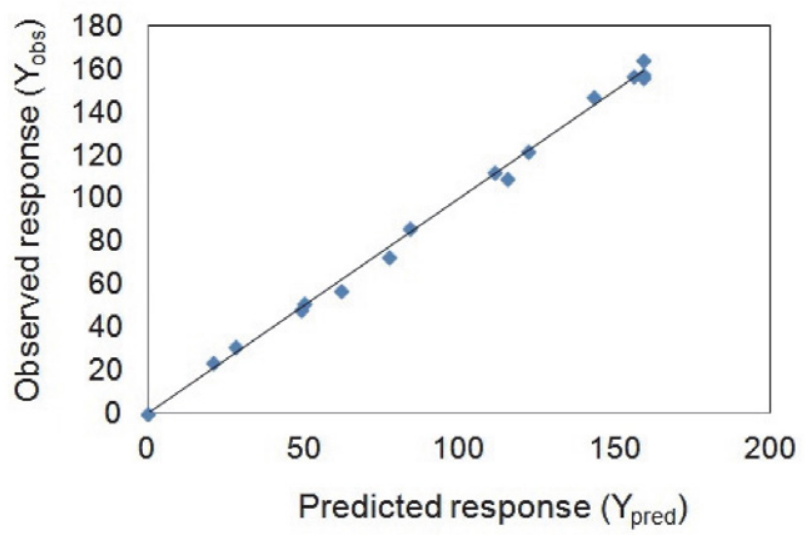

Figure 2. Parity plot showing the goodness-of-fit for RSM model $\left(\mathrm{R}^{2}=99.5 \%\right)$.
The fitting quality of RSM model is also shown by the results of analysis of variance (ANOVA, Table 3 ) which indicate that the model is adequate to represent the actual relationship between response $(\mathrm{Y})$ and the significant variables. ${ }^{11}$ The low values of residual errors and the no significance of the lack of fit, show that the quadratic model obtained by the RSM approach using Box-Behnken design can be accepted to describe the studied phenomenon (Table 3).

The best way to predict the relationship between response and parameters of the interactions is to analyze the contour plots and the response surface graphs that give a detailed presentation of the optimum value predicted from the results. ${ }^{21,22}$ Each plot and graph that gives the variation of the lipase activity $(\mathrm{Y})$ with independent variables represent an infinite number of combinations of two test variables with the other two fixed at their respective zero level (Figure 3 ). The contour plots and 3D response surface graphs represented in Figure 3 show that the lipase activity $(\mathrm{U} / \mathrm{mL})$ was enhanced by the values near the middle of the input variables.

\section{3. Artificial Neural Network (ANN) Analysis}

The ANN architectures used in this purpose was a multilayer forward neural network trained with a Multi Layer Perceptron (MLP) incremental back propagation network with linear transfer function for output and $\operatorname{TanH}$ transfer function for hidden neurons. The input layer consists of incubation temperature $\left(\mathrm{X}_{1}\right)$, cultivation time $\left(\mathrm{X}_{2}\right)$, and Tween $80(\mathrm{v} / \mathrm{v})$ as carbon source $\left(\mathrm{X}_{3}\right)$. The output is represented by the activity of lipase produced by strain Cpt29. In order to select the optimal neural network architecture, which is an important test for a successful application, several ANN architectures (the number of hidden layers and the type of transfer functions), the top three ANN models are summarized in Table 4.

According to the values of coefficient of determination $\left(\mathrm{R}^{2}\right)$ and absolute average deviation (AAD) which indicate the significance of the model, we have used the three hidden layers to evaluate the ANN performance analysis compared with RSM one (Figure 4a). ANN analysis was

Table 3. ANOVA for the obtained model of RSM (Eq. 3).

\begin{tabular}{lccccc}
\hline Source & DF & Sum of squares & Least square mean & F & $P$-value \\
\hline Regression & 6 & 35018 & 5896 & 292.42 & 0.000 \\
Linear & 3 & 21369 & 5766 & 289.00 & 0.000 \\
Square & 3 & 13649 & 4550 & 228.00 & 0.000 \\
Residual Error & 8 & 160 & 20 & 221.00 & 0.000 \\
Lack of fit & 6 & 125 & 21 & 1.20 & $0.520>>\alpha=0.05$ \\
Pure Error & 2 & 35 & 17 & & \\
Total & 14 & 35177 & & &
\end{tabular}

DF: degree of freedom. $P$ significant if value less than $0.05 . \mathrm{R}^{2}=99.6 \%$ 
a)

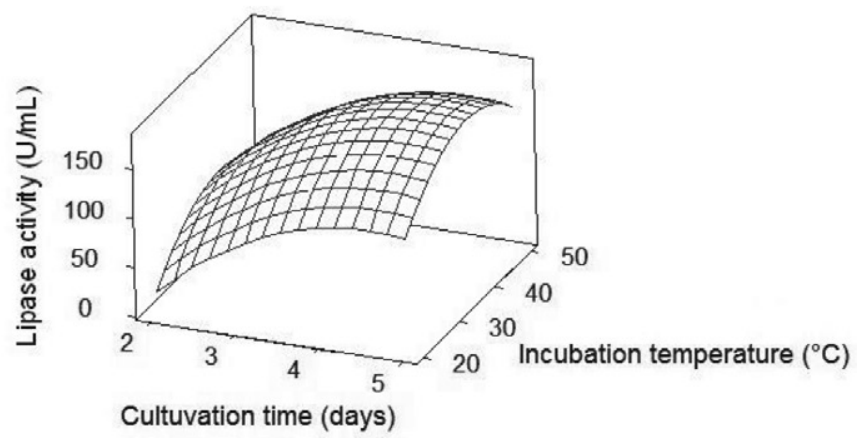

b)

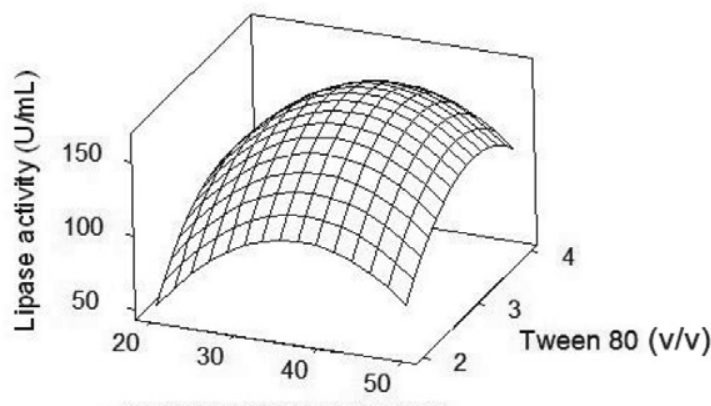

Incubation temperature $\left({ }^{\circ} \mathrm{C}\right)$

c)

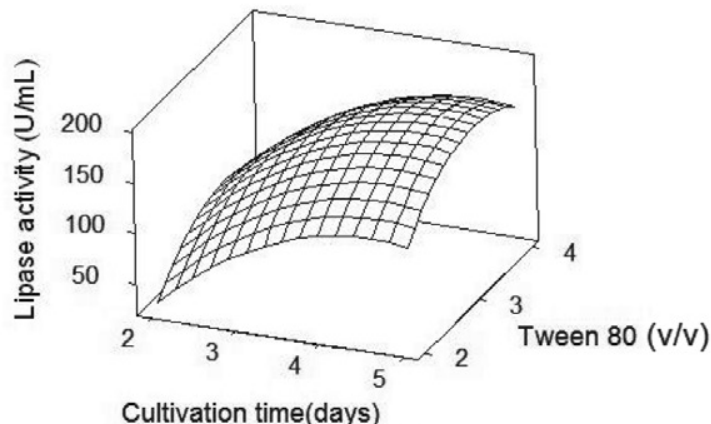

d)

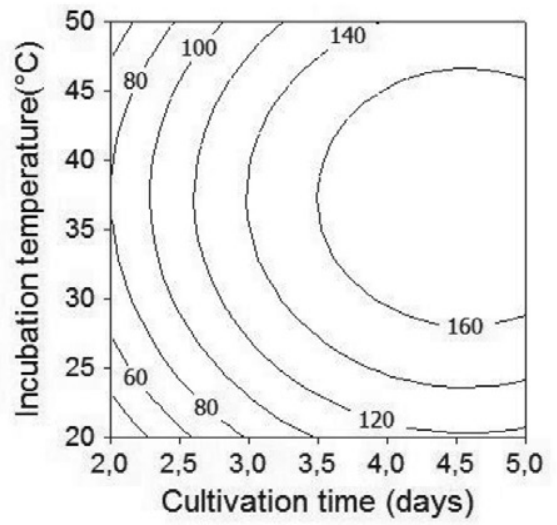

e)

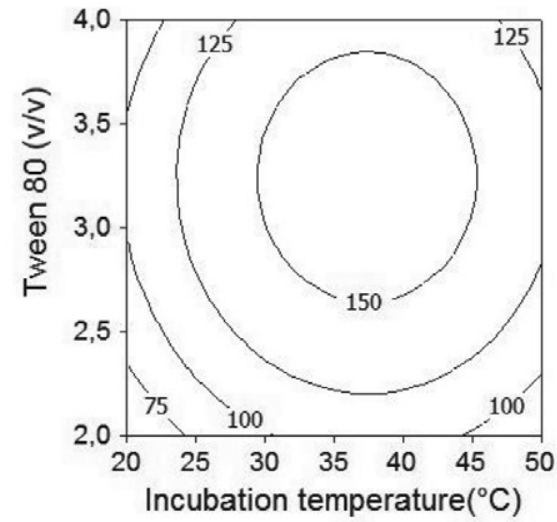

f)

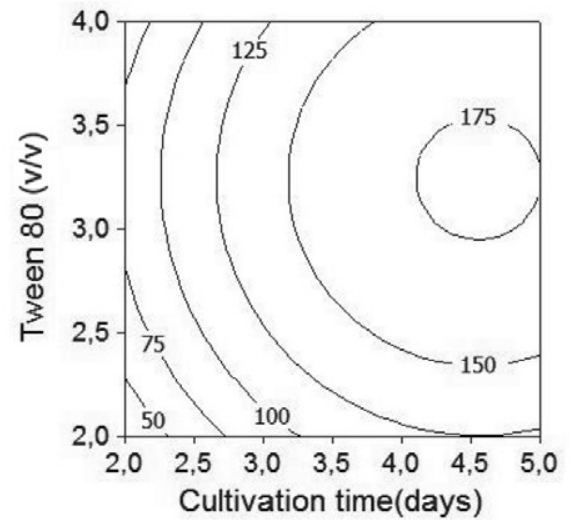

Figure 3. Response surface graphs with contour plots for the effects of independent variables on lipase activity (U/mL), and their mutual interactions, respectively: incubation temperature and cultivation time (a) and (d), incubation temperature and Tween 80 (v/v) (b) and (e), cultivation time and Tween $80(\mathrm{v} / \mathrm{v})(\mathrm{c})$ and (f).

conducted using SAS software (SAS software, version 9.0, SAS Institute, Inc., Cary, NC). The validity of the ANN (33-1) model for testing data is confirmed by the goodness of fit between predicted and experimental response values (Figure $4 b, R^{2}=99.9 \%$ ).

\section{4. Comparison of RSM and ANN Models}

The observed values of the lipase activity $(\mathrm{Y})$ along with the predicted ones calculated by ANN and RSM (Table 1) show the goodness of fit for the corresponding

Table 4. Significant ANN architectures and their effects on the estimation and prediction of lipase activity (Y).

\begin{tabular}{lccccccc}
\hline Model & $\begin{array}{c}\text { Learning } \\
\text { Algorithm }\end{array}$ & $\begin{array}{c}\text { Transfer function, } \\
\text { output }\end{array}$ & $\begin{array}{c}\text { Transfer function, } \\
\text { hidden neurons }\end{array}$ & $\begin{array}{c}\text { Training set, } \\
\mathbf{R}^{\mathbf{2}} \mathbf{( \% )}\end{array}$ & $\begin{array}{c}\text { Validation set, } \\
\mathbf{R}^{\mathbf{2}} \mathbf{( \% )}\end{array}$ & $\begin{array}{c}\text { Training set, } \\
\text { AAD }\end{array}$ & $\begin{array}{c}\text { Validation set, } \\
\text { AAD }\end{array}$ \\
\hline $3-3-1$ & MLP & Linear & Tanh & 99.73 & 99.80 & 0.013 & 0.0002 \\
$3-2-1$ & MLP & Linear & Tanh & 95.12 & 95.10 & 0.055 \\
$3-1-1$ & MLP & Linear & Tanh & 79.24 & 76.60 & 0.114 & 0.0007 \\
\hline
\end{tabular}


a)

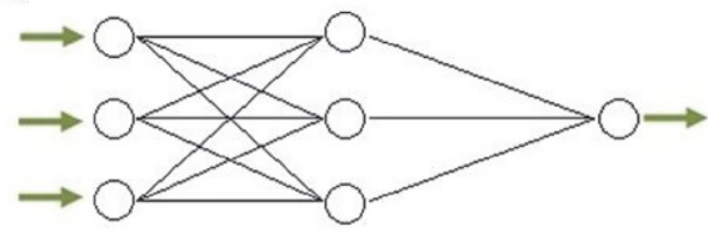

Input layers Hidden layers Output layer

b)

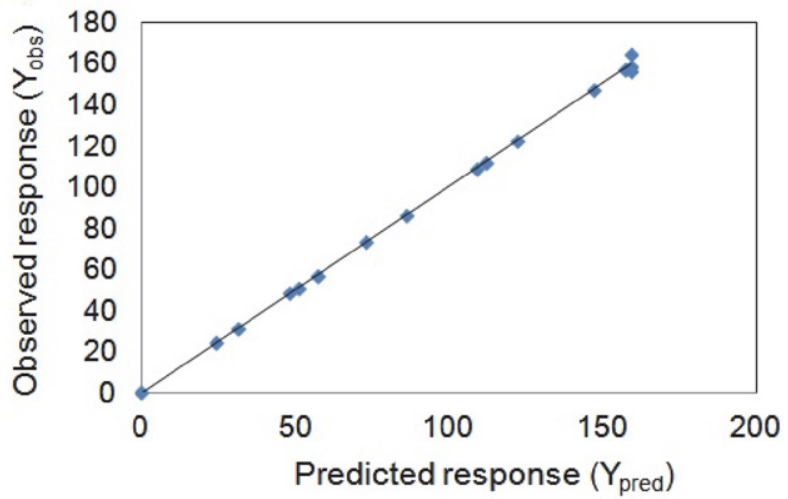

Figure 4. Neural network architecture used for the prediction of lipase activity (a). Parity plot showing the goodness-of-fit for RSM model $\left(\mathrm{R}^{2}=99.9 \%\right)(\mathrm{b})$.

models $\left(\mathrm{R}^{2}=99.9 \%\right.$ and $99.5 \%$, for ANN and RSM, respectively). Both performed models provided good quality predictions, yet the ANN showed a clear superiority over RSM for both data fitting and estimation capabilities (Figures 2 and $4 \mathrm{~b}$ ).

\section{5. Optimization of the Response (Y)}

The optimal point of culture parameters for maximum lipase production was determined by the desirability function of Minitab software. The optimal lipase production expressed by lipase activity $(\mathrm{U} / \mathrm{mL})$ corresponds relatively to the middle values of the three powerful factors (Figure 5). Experimental validation of enzyme activity was performed using optimal operating variables which were set to incubation temperature of $37.9^{\circ} \mathrm{C}, 111 \mathrm{~h}$ of cultivation time, and $3.27 \%(\mathrm{v} / \mathrm{v})$ Tween 80 .The experimental obtained value of the lipase activity $(188 \mathrm{U} / \mathrm{mL})$ is upper than the theoretical value $(179.9 \mathrm{U} / \mathrm{mL})$.

Furthermore, the lipase activity from Actinomadura keratinilytica strain Cpt29 as a thermophilic actinomycete, was found to be significantly superior than several ones reported previously for the most of the other actinomycetes (Table 5).

\section{6. Partial Purification of AKL29}

Extracellular lipase was partially purified to homogeneity from the culture filtrates of Actinomadura keratinilytica strain Cpt 29 grown on Tween 80 under optimal culture conditions. The crude enzyme was precipitated using acetone to yield as an active pellet. Next the obtained supernatant was applied onto a column $(3 \mathrm{~cm} \times 160 \mathrm{~cm})$ of gel filtration Sephacryl S-75 equilibrated with buffer solution of Tris- $\mathrm{HCl}(20 \mathrm{mM} ; \mathrm{pH}$ 8) containing $1 \mathrm{mM}$ benzamidine. Figure 6 presents the proteine elution profile

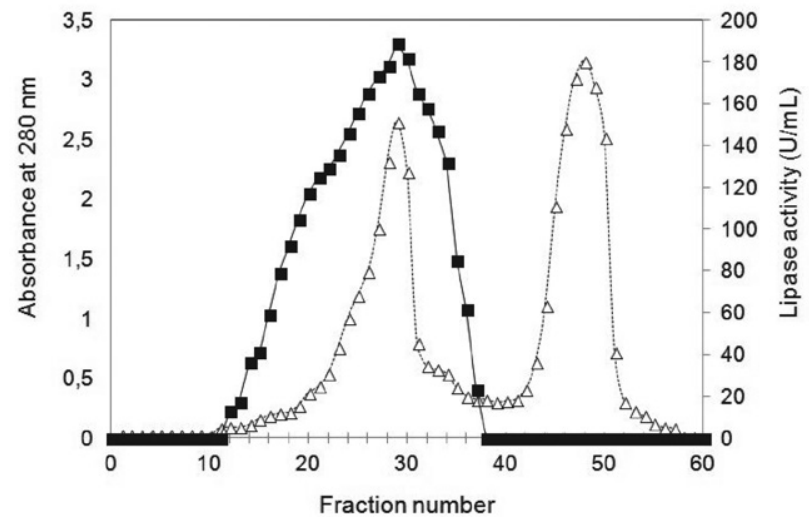

Figure 6. Elution profile of AKL29 obtained by gel filtration using chromatography on Sephacryl S-75. The column $(3 \mathrm{~cm} \times 160 \mathrm{~cm})$ was equilibrated with buffer: $20 \mathrm{mM}$ Tris- $\mathrm{HCl}, \mathrm{pH} 8$, and $1 \mathrm{mM}$ benzamidine. The elution of lipase $(2 \mathrm{~mL})$ was performed at a rate of $45 \mathrm{ml} / \mathrm{h}$. Lipase activity (-) was measured as described in materials and methods section, and the protein $(\Delta)$ was monitored by absorbance at $280 \mathrm{~nm}$.

\begin{tabular}{|c|c|c|c|}
\hline $\begin{array}{cl}\text { Optimal } & \text { High } \\
D^{-} & \text {High } \\
1.0000 & \text { Cur } \\
& \text { Low } \\
\end{array}$ & $\begin{array}{c}\text { Time } \\
5.0 \\
{[4.6061]} \\
2.0 \\
\end{array}$ & $\begin{array}{c}\text { Temperature } \\
50.0 \\
{[37.8788]} \\
20.0 \\
\end{array}$ & $\begin{array}{c}\text { Tween } 80 \\
4.0 \\
{[3.2727]} \\
2.0 \\
\end{array}$ \\
\hline $\begin{array}{l}\text { Lipase activity (y) } \\
\text { Maximum } \\
y=179.9730 \\
d=1.0000\end{array}$ & & & \\
\hline
\end{tabular}

Figure 5. Composite desirability and optimization plot for maximum lipase activity. 
Table 5. Lipase activity recorded in some Actinomycetes.

\begin{tabular}{|c|c|c|c|c|c|}
\hline Organism & Substrate & $\begin{array}{l}\text { Optimum pH } \\
\text { and temperature }\end{array}$ & $\begin{array}{c}\text { Cultivation } \\
\text { time (h) }\end{array}$ & $\begin{array}{c}\text { Lipase } \\
\text { activity }(\mathrm{U} / \mathrm{mL})\end{array}$ & Reference \\
\hline Actinomadura keratinilytica strain Cpt29 & Tween 80 & 8 and $37.9^{\circ} \mathrm{C}$ & 111 & 188 & This work \\
\hline Streptomyces sp. Al-Dhabi- 49 & Glucose & 8 and $35^{\circ} \mathrm{C}$ & 120 & 162 & 5 \\
\hline Streptomyces variabilis NGP 3 & Lactose & 8.5 and $45^{\circ} \mathrm{C}$ & 168 & 39.4 & 23 \\
\hline Streptomyces exfoliates & Triacylglycerides & 6 and $37^{\circ} \mathrm{C}$ & 72 & 6.9 & 24 \\
\hline Streptomyces sp. TEM 33 strain & $p$-nitrophenyl palmitate & 9 and $37^{\circ} \mathrm{C}$ & 36 & 3 & 25 \\
\hline
\end{tabular}

Table 6. Flow sheet of the AKL29 partial purification.

\begin{tabular}{lccccc}
\hline Purification step & $\begin{array}{c}\text { Total activity } \\
(\mathbf{U})\end{array}$ & $\begin{array}{c}\text { Protein amount } \\
(\mathbf{m g})\end{array}$ & $\begin{array}{c}\text { Specific activity } \\
(\mathbf{U} / \mathbf{m g})\end{array}$ & $\begin{array}{c}\text { Activity recovery } \\
\text { (\%) }\end{array}$ & $\begin{array}{c}\text { Purification } \\
\text { factor }\end{array}$ \\
\hline Culture supernatant & $31800 \pm 1200$ & $450 \pm 36$ & $70 \pm 1.5$ & 100 & 1 \\
Acetone precipitation & $30000 \pm 700$ & $89 \pm 4$ & $337 \pm 2.7$ & 94 & 5 \\
S-75 chromatography & $7800 \pm 165$ & $4 \pm 0.4$ & $1880 \pm 79$ & 24.5 & 27 \\
\hline
\end{tabular}

${ }^{\mathrm{a}} 1 \mathrm{U}$ corresponds to $1 \mu \mathrm{mol}$ of fatty acid released per minute using olive oil emulsion as substrate. ${ }^{\mathrm{b}}$ Protein amounts were estimated using Bradford's method.

recorded at the final step of the lipase patial purification. The specific activity of the pure lipase increased 27 -fold compared to the crude extract (Table 6).

\section{7. Kinetic Study of AKL29}

The ability of our partially purified lipase to hydrolyse its substrate without any surfactant, was also tested using the linear kinetic of FAAs release up on olive oil emulsion hydrolysis biocatalyzed by the partially purified lipase (AKL29) for $12 \mathrm{~min}$. The results (Figure 7a) indicate that the lipase was efficient and seems to be resistant to interfacial denaturation at lipids-water interfaces. The presence of interfacial activation phenomenon of AKL29 was assessed by studying the rate of hydrolysis of TC3 emulsified in $0.33 \%$ gum arabic and $0.15 \mathrm{M} \mathrm{NaCl}$ by AKL29 as a function of the concentration of the substrate. As shown

a)

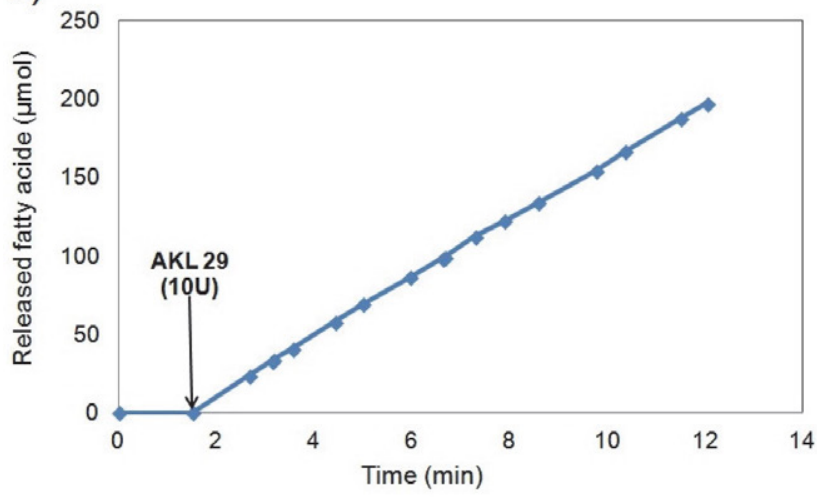

in Figure 7b, when TC3 was in the water-soluble state, AKL29 hydrolyzed slowly his substrate. However, the lipase activity increased rapidly above the solubility limit of TC3 to reach $100 \%(300 \mathrm{U} / \mathrm{mg})$ at $34 \mathrm{mM}$. This result indicates that the AKL29 presents the interfacial activation phenomenon. AKL29 which hydrolyses olive oil emulsion, can be considered as a true lipase. ${ }^{26}$

\section{8. Compatability and Stabilty of Partially Purified AKL29 with Laundry Detrgents}

On the basis of the lipase kinetic study, the stability and compatibility of AKL29 with various commercial laundry detergents have been investigated. Both the compatibility and the stability of AKL29 as a bio-additive in laundry detergents were evaluated by comparison with commercial Candida rugosa lipase (CRL). The results (Figure 8) show

b)

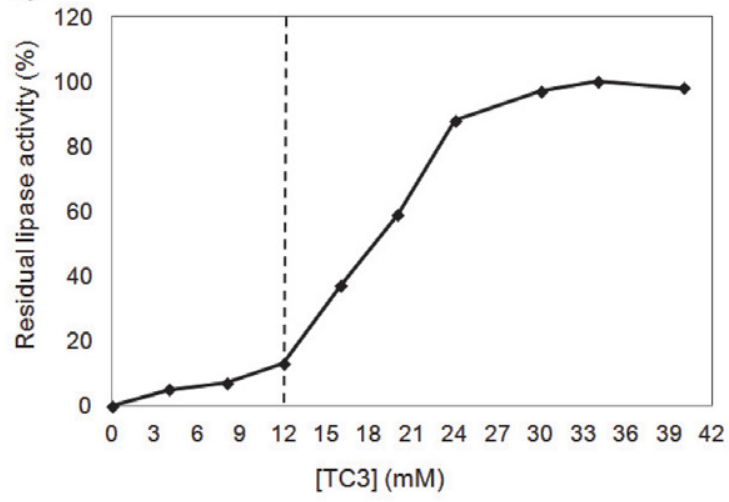

Figure 7. Parity plot showing kinetic study of lipase using olive oil emulsions as substrate (a). Hydrolysis rate of TC3 by AKL29 as function of substrate concentration. The TC3 solutions were systematically prepared by mixing $(3 \times 30 \mathrm{~s})$ in a warring blender agiven amount of TC 3 in $30 \mathrm{ml}$ of $0.33 \% \mathrm{GA}$ and $0.15 \mathrm{M} \mathrm{NaCl}$. The release of propionic acid was recorded continuously at $\mathrm{pH} 8$ and $45^{\circ} \mathrm{C}$ using a pH-stat. The solubility limit of TC3 $(12 \mathrm{mM})$ is indicated by a vertical dotted line (b). 
that the lipase exhibited high stability and significant compatibility at $40^{\circ} \mathrm{C}$ after $60 \mathrm{~min}$ of incubation in various laundry detergents compared to CRL. In fact, $100 \%$ of residual activity of AKL29 was recorded in the presence of NICE and ISIS. However, the results show a decrease in the residual activity of AKL29 with the other detergents tested. About $91 \%, 85 \%$ and $73 \%$ of residual activity was retained in the presence of OMO, ARIEL, and LE CHAT respectively. On the other hand, a slightly better compatibility and stability of commercial CRL were observed with OMO compared with AKL29 (Figure 8). According to these results, the lipolytic activity of AKL29 could be a potential candidate as a bio-additive for laundry detergent formulations.

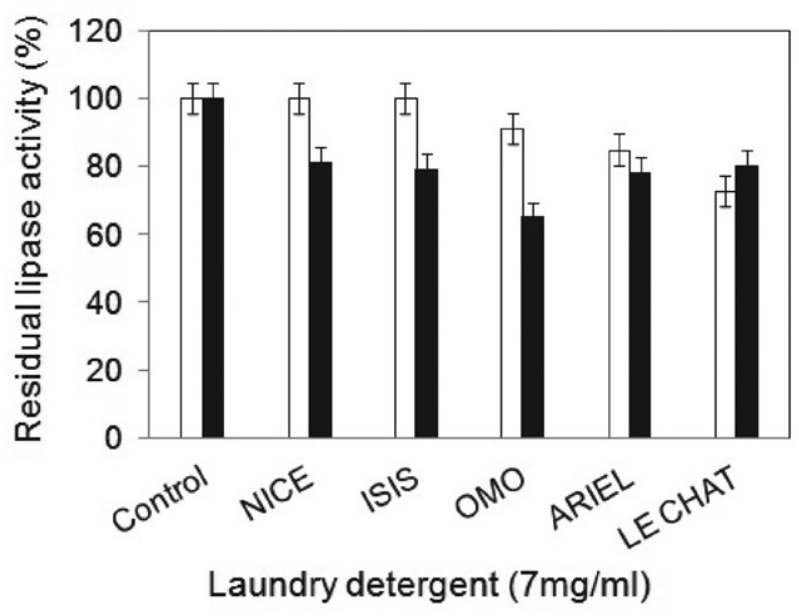

Figure 8. Residual activities of AKL29 ( $\square$ ) and CRL ( $\bullet$ ) in the presence of various commercial laundry detergents: enzymes were incubated for $60 \mathrm{~min}$ at $40{ }^{\circ} \mathrm{C}$ in the presence of detergents at a final concentration of $7 \mathrm{mg} / \mathrm{mL}$. The residual activities were determined at pH 8 and $45^{\circ} \mathrm{C}$ using olive oil emulsion as a substrate. Enzymes activities determined without any detergent and incubated under the similar conditions, were taken as $100 \%$ (control). The experiments were conducted three times and standard errors are reported. Vertical bars indicate standard error of the mean.

\section{9. Wash Performance Test of Partially Purified AKL29}

Partially purified lipase AKL29 was added in various laundry detergents to verify its effect on cleaning grease stains (Table 7). AKL29 showed high rates of olive oil removal compared with detergent alone which gives this novel lipase the advantage of its inclusion in some of laundry detergent formulation.

Table 7. Effect of partially purified AKL29 on removing sample stains from fat / fat (olive oil) sauce from cotton fabric with various commercial laundry detergents.

\begin{tabular}{lcc}
\hline $\begin{array}{l}\text { Laundry detergent } \\
(7 \mathbf{m g} / \mathbf{m L})\end{array}$ & \multicolumn{2}{c}{ Oil removal (\%) } \\
Detergent & Detergent + AKL29 \\
\hline ISIS & $40 \pm 0.7$ & $98 \pm 1.4$ \\
ARIEL & $28 \pm 1.2$ & $81 \pm 1,3$ \\
LE CHAT & $35 \pm 1.9$ & $79 \pm 1.7$ \\
OMO & $32 \pm 0.6$ & $70 \pm 0.8$ \\
NICE & $30 \pm 1.3$ & $62 \pm 0.7$ \\
\hline
\end{tabular}

The washing performance of the partially purified AKL29 was evaluated using visual examination of the removal of fat/greasy material stains on cotton fabrics. The washing performance of AKL29 as a bio-additive in several brand laundry detergents was evaluated compared to the control (Figure 9).

\section{Conclusion}

This work describes the optimization process of a new lipase produced from a thermophilic Actinomycete Actinomadura keratinilytica strain Cpt29 isolated from poultry compost in north-east of Algeria. The optimization

\section{a)}

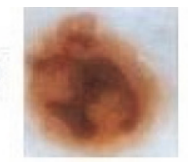

b)

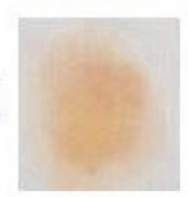

c)

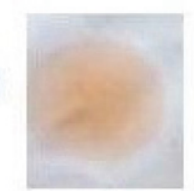

NICE
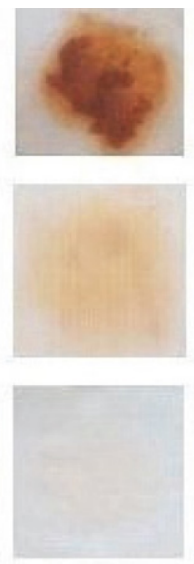

OMO
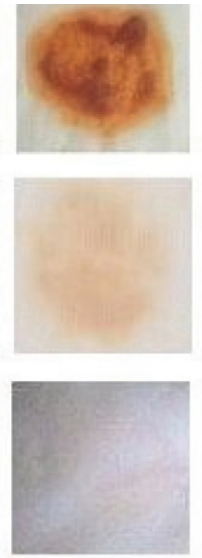

LE CHAT
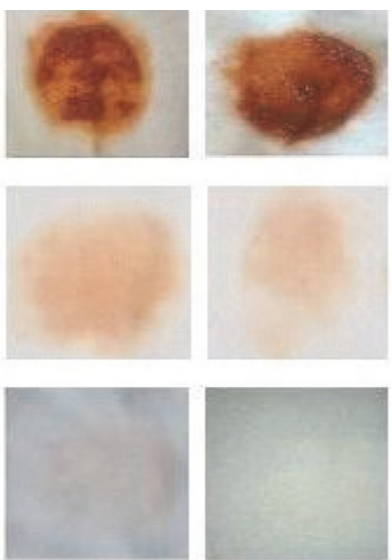

ARIEL
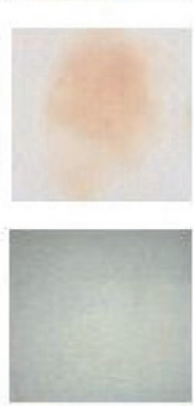

ISIS

Figure 9. Cloth pieces stained with mixture of sauce sample and fat/greasy material, were washed with commercial laundry detergent (7 mg/mL) added with AKL29 (50 U/mL). Untreated cloth pieces taken as control (a), and treated cloth pieces by detergent alone (b), and treated cloth pieces by detergent with lipase (c). 
study using artificial neural network (ANN) and response surface methodology (RSM) approaches, revealed significant improvement in lipase activity with optimal culture conditions. Maximum lipase production of $188 \pm 3 \mathrm{U} / \mathrm{ml}$ was obtained in Tween $80(3.27 \%, \mathrm{v} / \mathrm{v})$, at $37.9^{\circ} \mathrm{C}$, and after $111 \mathrm{~h}$ of cultivation. An overall 4.1 -fold increase in lipase production was recorded under optimized culture medium. Partial purification using acetone precipitation, and gel filtration on Sephacryl S-75, increased significantly the specific activity of AKL29. Finally, as commercial application, AKL29 exhibited good stability, high compatibility, and significant wash performance with various brand laundry detergents that make this novel lipase a suitable bio-additive for various detergents and a potential biocatalyst for subsequent industrial applications. According to these results, additional studies are underway by the laboratory team to better assess the lipase efficiency.

\section{Acknowledgements}

This work was generously supported by The General Directorate for Scientific Research and Technological Development (DG-RSDT), Algerian Ministry of Scientific Research.

\section{References}

1. O. Ilesanmi, A. E. Adekunle, J. A. Omolaiye, E. M. Olorode, A. L. Ogunkanmi, Scientific African, 2020, 8, e00279.

DOI:10.1016/j.sciaf.2020.e00279

2. D. Kirsh, Bot Gaz, 1935, 97, 321-333. DOI:10.1086/334555

3. F. Hasan, A. A. Shah, A. Hameed, Enzym Microb Technol, 2006, 39, 235-251. DOI:10.1016/j.enzmictec.2005.10.016

4. N. A. Al-Dhabi, A. K. M. Ghilan, G. A. Esmail, M. V. Arasu, V. Duraipandiyan, K. Ponmurugan, J Infect Public Health, 2019, 12, 549-556. DOI:10.1016/j.jiph.2019.01.065

5. N .A. Al-Dhabi, G. A. Esmail, A. K. M. Ghilan, M. V. Arasu, Saudi J Biol Sci, 2020, 27, 474-479.

DOI:10.1016/j.sjbs.2019.11.011

6. R. Gupta, N. Gupta, P. Rathi, Appl Microbiol Biot, 2004, 64, 763-781. DOI:10.1007/s00253-004-1568-8

7. R. Sharma, Y. Chisti, U. Banerjee, Biotechnol Adv, 2001, 19, 627-662. DOI:10.1016/S0734-9750(01)00086-6

8. B. Andualema, A. Gessesse, Biotechnol, 2012, 11, 100-118. DOI:10.3923/biotech.2012.100.118

9. R. Malathu, S. Chowdhury, M. Mishra, S. Das, P. Moharana, J. Mitra, U.K. Mukhopadhyay, A. R. Thakur, S.R, Am J Appl Sci, 2008, 5, 1650-1661. DOI:10.3844/ajassp.2008.1650.1661

10. M. Basri, R. N. Zaliha Raja Abd Rahman, A. Ebrahimpour, A. B. Salleh, E. R. Gunawan, M.B. Abd Rahman, BMC Biotechnol, 2007, 7, 1472. DOI:10.1186/1472-6750-7-53

11. F. Benamia, S. Bouchagra, Y. Saihi, Z. Djeghaba, N. Rebbani, Prep Biochem Biotechnol, 2013, 43, 33-47.

DOI:10.1007/s11696-016-0080-9
12. L. M. Colla, A. L. Primaz, S. Benedetti, R. A. Loss, M. De Lima, C.O. Reinehr, T.E. Bertolin, J.A.V. Costa, Braz J Microbiol, 2016, 47, 461-467. DOI:10.1016/j.bjm.2016.01.028

13. A. Habbeche, B. Saoudi, B. Jaouadi, S. Haberra, B. Kerouaz, M. Boudelaa, A. Badis, A. Ladjama, J Biosci Bioeng, 2014, 117, 413-421. DOI:10.1016/j.jbiosc.2013.09.006

14. M. Mandels, J. Weber, Advances in Chemistry, 1969, 95, 391413. DOI:10.1021/ba-1969-0095.ch023

15. I. Belhaj-Ben Romdhane, A. Fendri, Y. Gargouri, A. Gargouri, H. Belghith, Biochem Eng J, 2010, 53, 112-120. DOI:10.1016/j.bej.2010.10.002

16. A. Tiss, F. Carriere, R. Verger, Anal Biochem, 2001, 294, 3643. DOI:10.1006/abio.2001.5095

17. J. Rathelot, R. Julien, P. Canioni, C. Coeroli, L. Sarda, Biochimie, 1975, 57, 1117-1122. DOI:10.1016/S0300-9084(76)80572-X

18. M. M. Bradford, Anal Biochem, 1976, 72, 248-254. DOI:10.1016/0003-2697(76)90527-3

19. E. Fic, S. Kedracka-Krok, U. Jankowska, A. Pirog, M. Dziedzicka-Wasylewska, Electrophoresis, 2010, 31, 35733579. DOI:10.1002/elps.201000197

20. S. Akmoussi-Toumi, S. Khemili-Talbi, I. Ferioune, S. Kebbouche-Gana, Int J Biol Macromol, 2018, 116, 817-830. DOI:10.1016/j.ijbiomac.2018.05.087

21. A. Guvenc, N. Kapucu, H. Kapucu, O. Aydogan, U. Mehmetoglu, Enzym Microb Technol, 2007, 40, 778-785. DOI:10.1016/j.enzmictec.2006.06.010

22. J. C. Santos, H. F. De Castro, World J Microbiol Biotechnol, 2006, 22, 1007-1011. DOI:10.1007/s11274-005-2818-3

23. K. Selvam, B. Vishnupriya, IJPSR, 2013, 4, 4281-4289. DOI:10.13040/IJPSR.0975-8232.4(11)

24. M. M. Aly, S. Tork, S. M. Al-Garni, L. Nawar, Afr J Microbiol Res, 2012, 6, 1125-1137. DOI:10.5897/AJMR11.1123

25. J. B. C. Dos Santos, R. G. Da Silva Cruz, P. W. Tardioli, Appl Biochem Biotechnol, 2017, 183, 218-240.

DOI:10.1007/s12010-017-2440-5

26. F. Ferrato, F. Carriere, L. Sarda, R. Verger, Methods in Enzymol, 1997, 286, 327-347. DOI:10.1016/S0076-6879(97)86018-1 


\section{Povzetek}

V tem delu smo se osredotočili na učinkovito, ekonomično ter okolju prijazno pridobivanje lipaze (AKL29), potencialno uporabne v pralni industriji, iz Actinomadura keratinilytica sev Cpt29, ki je bil izoliran iz perutninskega komposta severovzhodne Alžirije. AKL29 kaže visoko lipazno aktivnost (45 U/mL) pri hidrolizi triacilglicerolov, kar potrjuje, da gre za pravo lipazo. Da bi dosegli maksimalno proizvodnjo lipaze smo s pomočjo RSM in ANN modelov optimirali kultivacijske parametre kot so temperatura inkubacije, čas kultivacije in koncentracijo Tween 80 (v/v). Rezultati so pokazali, da oba modela dajeta dobre kvalitativne napovedi, da pa kaže ANN model znatno boljše napovedi in ujemanje z eksperimentalnimi podatki. Pod optimalnimi pogoji (temperatura inkubacije $37.9^{\circ} \mathrm{C}$, čas kultivacije $111 \mathrm{~h}$, koncentracija Tween 803.27 \% v/v) smo dosegli 4.1-kratni porast proizvodnje lipaze. Delno očiščena lipaza kaže dobro stabilnost in visoko kompatibilnost ter zmožnost spiranja v kombinaciji s pralnimi detergent, zaradi česar je obetaven kandidat za uporabo v pralni industriji. 